\title{
ОПТИМІЗАЦІЯ ЗМІНИ ПОВЕДІНКИ ПАЦІЄНТІВ ЯК ОДИН ІЗ ЕЛЕМЕНТІВ МОДЕЛІ ПРОФІЛАКТИКИ ТА НАДАННЯ ІНТЕНСИВНОЇ МЕДИЧНОЇ ДОПОМОГИ ХВОРИМ НА ІНФАРКТ МІОКАРДА
}

\begin{abstract}
Резюме. Одним з визначальних фракторів здоров'я людини є стиль життя. На жаль, багато пацієнтів не дотримується рекомендацій лікарів щодо усунення фракторів ризику (ФР) розвитку серцево-судинної патології. Аналіз даних Національного дослідження стану здоров'я та харчування населення (The National Health and Nutrition Examination Survey, III, США) продемонстрував низький рівень дотримання рекомендацій Американської асоціації серця з профрілактики серцево-судинних захворювань (ССз). Мета дослідження - адаптація "моделі 5А" у пацієнтів із ФР розвитку інсраркту міокарда (IM).

Матеріали і методи. У дослідженні використано дані з медичних карт стаціонарного хворого 288 пацієнтів 3 ІМ. Використано методи: викопіювання даних, статистичний, аналітичний.

Результати досліджень та їх обговорення. У дослідженні акцентовано увагу на такому факторі ризику розвитку інораркту міокарда, як гіпертонічна хвороба. Запропоновано модель профілактики та надання інтенсивної медичної допомоги хворим на інсаркт міокарда. Одним із елементів цієї моделі показано адаптовану "модель 5А" для запобігання розвитку інфаркту міокарда у пацієнтів із наявною гіпертонічною хворобою.

Висновки. "Модель 5А", яку ми запропонували для консультування щодо зміни поведінки пацієнтів з наявною гіпертонічною хворобою (ГХ), як фактором ризику (ФР) розвитку ІМ, дозволить підвищити відповідальність пацієнта за стан свого здоров'я та забезпечити їх ранню госпіталізацію у лікувально-профрілактичні заклади.
\end{abstract}

Ключові слова: фрактори ризику; інфраркт міокарда; гіпертонічна хвороба; профілактика; "модель 5А”.

ВСтУП Одним з визначальних фракторів здоров'я людини є стиль життя. На жаль, багато пацієнтів не дотримується рекомендацій лікарів щодо усунення фракторів ризику (ФР) розвитку серцево-судинної патології. Аналіз даних Національного дослідження стану здоров'я та харчування населення (The National Health and Nutrition Examination Survey, III, США) продемонстрував низький рівень дотримання рекомендацій Американської асоціації серця 3 профілактики серцево-судинних захворювань (СС3). Лише менше 7,5 \% учасників виконували 6-7 порад із 7 існуючих, до яких належали підтримка оптимальної маси тіла, цільового рівня артеріального тиску, глюкози у плазмі крові, загального холестерину, відмова від тютюнокуріння, достатня фрізична активність та здорове харчування [1], а більше третини не отримували свою оптимальну комбінацію препаратів для вторинної просрілактики [2]. Подібна ситуація спостерігається і в країнах Європи, у тому числі й в Україні.

Низка проведених досліджень вказує на недостатність застосування в Україні Європейських рекомендацій 3 вторинної профрілактики ішемічної хвороби серця (IXC) у повсякденній клінічній практиці.

Метою дослідження була адаптація "моделі 5A" у пацієнтів з ФР розвитку інфраркту міокарда (IM).

МАТЕРІАЛИ І МЕТОДИ У дослідженні використано дані 3 медичних карт стаціонарного хворого 288 пацієнтів з IM, які перебували на стаціонарному лікуванні в Тернопільській комунальній міській лікарні № 2. Використано методи: викопіювання даних, статистичний, аналітичний.

РЕЗУЛЬТАТИ ДОСЛІДЖЕНЬ ТА ЇХ ОБГОВОРЕННЯ Згідно з підсумками Державної програми профрілактики та лікування артеріальної гіпертензії в Україні, відповідну терапію щодо зниження рівня артеріального тиску в 2000 р. отримували $28,9 \%$, у 2005 р. - 48,0 \%, в 2010 р. - 37,5 \% пацієнтів від усіх осіб, які знали про наявність у них підвищеного артеріального тиску [3]. Проте показник досягнення цільового рівня артеріального тиску становив лише 8,0 \% у сільських жителів та менше 15,0 \% - у міських [4].

Унісіковані клінічні протоколи медичної допомоги хворим на ССЗ, зокрема гіпертонічної хвороби (ГХ), пе- редбачають серед низки обов'язкових завдань лікаря первинної ланки проведення первинної профілактики, яка полягає у виявленні й корекції доведених ФР [5].

Проте проведені дослідження вказують на низьку есрективність диспансеризації хворих та недостатній рівень санітарно-просвітницької роботи сімейних лікарів. За даними Інституту кардіології АМН України, рекомендації щодо профрілактики хвороб системи кровообігу (ХСК) та з питань здорового способу життя отримують не більше 10,0 \% хворих. Мають інфрормацію про профрілактику $\Gamma X-26,8$ \% людей. Національне опитування населення України з проблеми тютюну (2005р.) засвідчило, що у 69,0 \% курців медичні працівники жодним чином не сприяли їхньому припиненню куріння, лише 25,0 \% 3 них рекомендували кинути курити і тільки 2,0 \% 3 останніх пропонували допомогу в позбавленні цієї шкідливої для здоров'я звички [6].

Частина медичних працівників не вважає своїм обов'язком проведення профрілактичної роботи, найбільш важливою вважають лікувальну роботу; обов'язкові діагностичні обстеження та профрілактичні втручання вони призначають лише особам з груп ризику або за наявності скарг пацієнта $[7,8]$.

Підтвердженням неефективного лікування та відсутності профілактичних дій серед пацієнтів працездатного віку є той сракт, що 8,8 \% хворих на ГХ перенесли IM або інсульт протягом року після встановлення їм діагнозу ГХ. 3 них 25,0 \% мали повторне ускладнення в той же рік, $37,5 \%$ - протягом 2 років, а 37,5\% - через 3 роки. Навіть наявність ускладнення не підвищила мотивацію до лікувально-профрілактичних заходів: лише 45,5 \% населення працездатного віку відвідало лікаря після ускладнення одноразово, після виписки із стаціонару [9]. За даними Кузбаського кардіологічного центру, лише половина пацієнтів через рік після проведення аортокоронарного шунтування дотримується рекомендацій лікаря і лише 9,0\% пацієнтів перестають курити [10].

70,8 \% хворих на ГХ, які проживають у сільській місцевості, вважають основою профрілактики свого захворювання контроль за показниками артеріального тиску. Лише 9,2 \% звертаються до лікаря з метою отримати консультацію щодо 
здорового способу життя і тільки 14,2 \% дотримуються його [11].

Для вирішення проблеми зростання захворюваності й поширеності неіноекційних захворювань, у тому числі й СС3 Світовий банк рекомендує такі шляхи: проведення основних економічно-ефективних заходів, спрямованих на поведінкові фрактори ризику, та переорієнтація системи охорони здоров'я на визначення груп ризику, своєчасне виявлення хронічних захворювань та станів і контроль їх розвитку [12].

У проекті наказу МОЗ України “Про затвердження та впровадження медико-технологічних документів зі стандартизації медичної допомоги в частині профрілактики серцево-судинних захворювань" передбачено виявлення у пацієнтів фракторів ризику, що сприяють розвитку ССЗ (тютюнокуріння, нераціонального харчування, низької срізичної активності); визначення у всіх осіб чоловічої статі від 40 років та жіночої статі від 50 років, у яких немає цукрового діабету, хронічної хвороби нирок або ССЗ, загального або відносного ризику розвитку ССЗ з використанням шкали SCORE (Systematic COronary Risk Evaluation), а також проведення низки клінічних досліджень: вимірювання АТ, визначення індексу IMT, реєстрація ЕКГ, лабораторні обстеження - загальний аналіз крові, загальний аналіз сечі, загальний холестерин, глікемія, креатинін. При цьому у всіх зазначених документах передбачається проведення немедикаментозної та/ або медикаментозної корекції фракторів ризику $[13,14]$.

Ми запропонували модель профрілактики та надання інтенсивної медичної допомоги хворим на IМ з урахуванням прогнозних тенденцій поширеності та захворюваності ХСК.

В основу моделі покладено взаємодію об'єднаних зусиль центральних органів влади, керівництва місцевих громад, лікарів різних рівнів надання медичної допомоги та самих громадян.

Ми розрахували прогнозні тенденції зростання рівня поширеності та захворюваності XСК, IXC та IM, що свідчать про їх зростання до 2025 р. відповідно на 59,6; 49,4 та 15,4 \% [15]. Для поліпшення ефрективності профрілактичної роботи лікарями доцільно виділити певні групи населення з метою диференційованого підходу до корекції певних ФР розвитку IM.

У нашому дослідженні в пацієнтів з IM ГX спостерігалася у 77,1 \%. Більшість 3 них хворіла на цію патологію більше 10 років (45,7 \%), 19,7 \% мали підвищений артеріальний тиск в анамнезі від 5 до 10 років, 34,5 \% - до 5 років. У 10,8 \% пацієнтів ІМ виник як ускладнення гіпертонічного кризу. На жаль, не всі хворі регулярно отримували антигіпертензивну терапію. Лише $46 \%$ осіб регулярно приймали призначену медикаментозну терапію, $33 \%$ - застосовували медикаменти нерегулярно або епізодично і 21 \% осіб взагалі не приймали ніяких антигіпертензивних середників.

При вивченні ФР, залежно від віку, було виділено певні особливості, притаманні кожній віковій групі, та відповідно сорормовано рекомендації. Так, серед пацієнтів віком до 44 років доцільно проводити корекцію поведінкових фракторів (відмова від куріння, алкоголю, раціональне харчування), здійснювати контроль ліпідограми. Особливо це стосується пацієнтів з обтяженим сімейним анамнезом.

У хворих старшої вікової групи більше уваги необхідно спрямувати на диспансерне спостереження за:

- жінками з наявністю ЦД 2 типу, стенокардії напруги, ГХ із довготривалим перебігом;
- чоловіками з порушенням ритму серця за типом срібриляції передсердь, курінням.

Через нестачу коштів обсяг діагностичних обстежень і можливості лабораторно-інструментального контролю за станом пацієнтів похилого віку з ГХ нижчі, ніж у хворих молодого й середнього віку, внаслідок чого спостерігається зростання частоти ускладнень ГХ, у тому числі й розвиток IM.

У чоловіків віком 45-59 років з наявністю ГХ необхідно особливу увагу звернути на дотримання рекомендацій щодо прийому антигіпертензивної терапії.

Важливо доносити до пацієнта інформацію про необхідність дотримання режиму праці та відпочинку, раціонального харчування, усунення або уникнення значних психоемоційних навантажень, регулярного медикаментозного лікування, корекції поведінкових ФР.

Проте ця робота не повинна стосуватися лише медичних працівників. Враховуючи важливість особистісного орактора в розвитку серцево-судинної патології та, зокрема IM, необхідно виробити у самих пацієнтів відповідальне ставлення до стану свого здоров'я.

Враховуючи зарубіжний досвід з мінімізації ФР неінфрекційних захворювань, ми запропонували адаптовану "модель 5А" щодо інтенсивного втручання на рівні первинної медичної допомоги для зміни поведінки пацієнтів із таким ФР розвитку IM, як ГХ в межах пацієнт-центрованого підходу в Україні, що складає один із елементів моделі надання допомоги хворим на IM.

Ця методика, названа так за літерами, з яких починаються ключові слова втручання англійською мовою (Ask, Assess, Advise, Agree та Assist) спочатку використовувалася в програмах з припинення куріння. В основі методу лежить чітко впорядкована комбінація мотиваційного інтерв'ювання та поведінкового консультування. Мотиваційне інтерв'ювання - це метод консультування для досягнення певної мети через пацієнт-центрований підхід, спрямований на зміни в поведінці пацієнта, при якому в центрі уваги знаходиться конкретний пацієнт 3 його проблемами і потребами (табл. ). У низці досліджень з вивчення втручань в первинній ланці встановлено, що цей метод є одним з найбільш ефективних у взаємодії між лікарем і пацієнтом [16].

Найкращий шлях ефрективної госпіталізації - екстрена медична допомога. Медичні працівники повинні знати, в яку клініку транспортувати пацієнта, користуватися послугами дистанційної ЕКГ-діагностики кардіологічних центрів.

У кожній області повинні бути створені відділення серцево-судинної та рентгеноендоваскулярної хірургії для надання невідкладної допомоги пацієнтам з IM (проведення стентування коронарних артерій) з урахуванням потреб населення щодо захворюваності ІМ. Ці відділення повинні функціонувати у складі багатопрофільних лікарень і забезпечувати реперфузійні процедури в найкоротші терміни від госпіталізації пацієнтів 24 год на добу, 7 днів на тиждень, 365 днів на рік. Тут повинні докласти свої зусилля територіальні та місцеві органи влади щодо матеріального забезпечення таких лікарень необхідними ресурсами.

Після проведеного стаціонарного лікування пацієнт повинен знову перебувати під диспансерним наглядом не лише кардіолога, а й сімейного лікаря та медичного психолога. Залучення сімейних лікарів у систему реабілітації та подальшого лікування пацієнтів із постінфрарктним кардіосклерозом необхідне для забезпечення 
Таблиця. Основні елементи “моделі 5А" для консультування щодо зміни поведінки пацієнтів із наявною ГХ, як ФР розвитку IM

\begin{tabular}{|c|c|}
\hline Дія (AAAAA) & Суть активності \\
\hline Спитати (Ask) & $\begin{array}{l}\text { Ініціювати обговорення відомих фракторів ризику виникнення інфраркту міокарда з конкретним пацієнтом } \\
\text { без будь-яких оціночних висловлювань та з'ясувати його готовність до змін } \\
\end{array}$ \\
\hline Оцінити (Assess) & $\begin{array}{l}\text { Оцінити конкретного пацієнта з точки зору ймовірності розвитку в нього IM залежно від статево-вікових } \\
\text { особливостей, наявності ГХ та тривалості її перебігу }\end{array}$ \\
\hline Порадити (Advise) & $\begin{array}{l}\text { Описати доцільність контролю свого здоров'я з метою раннього виявлення симптомів ІМ, ризики, } \\
\text { пов'язані з пізньою госпіталізацією у лікувально-просрілактичні заклади }\end{array}$ \\
\hline Домовитися (Agree) & $\begin{array}{l}\text { Досягти домовленості між лікарем і пацієнтом стосовно очікуваних результатів і цільових орієнтирів, } \\
\text { що відповідають SMART* (наприклад, при перших проявах хвороби пацієнти повинні знати коли і } \\
\text { куди повідомити про симптоми захворювання, найефективніші шляхи госпіталізації у лікувально- } \\
\text { профрілактичні заклади, сучасні високоефективні методи лікування IM) }\end{array}$ \\
\hline Допомогти (Assist) & $\begin{array}{l}\text { Допомогти пацієнтам із ГХ, як ФР розвитку ІМ, спланувати та розробити поетапне досягнення цільових } \\
\text { орієнтирів у боротьбі з підвищеним артеріальним тиском (регулярність контролю артеріального } \\
\text { тиску та прийому антигіпертензивних препаратів, дотримання режиму праці та відпочинку, усунення } \\
\text { або уникнення значних психоемоційних навантажень, раціональне харчування). Ці етапи можуть } \\
\text { супроводжуватися як регулярним контролем сімейного лікаря та медичної сестри, так й інших фрахівців } \\
\text { (медичного психолога, дієтолога, фрахівця з лікувальної фрізкультури тощо) }\end{array}$ \\
\hline
\end{tabular}

Примітка. * тобто бути конкретними, вимірними, досяжними, реалістичними і досягатися до певного терміну.

контролю за пацієнтами після реваскуляризаційних процедур. Таким чином, відбудеться адекватна інтеграція сімейної медицини у спеціалізовану систему ведення пацієнтів після реперфузійної терапії.

вИСнОВкИ "Модель 5А", яку ми запропонували для консультування щодо зміни поведінки пацієнтів 3 наявною
ГХ, як ФР розвитку ІМ, дозволить підвищити відповідальність пацієнта за стан свого здоров'я та забезпечити їх ранню госпіталізацію у лікувально-просрілактичні заклади.

Перспективи подальших досліджень полягають у вивченні ефективності впровадження запропонованої моделі у практику сімейного лікаря.

\section{СПИСОК ЛІТЕРАТУРИ}

1. Charakida M. The Year in Cardiology 2012: focus on cardiovascular disease prevention / M. Charakida, S. Masi, J. E. Deanfield // Eur. Heart J. - 2013. - Vol. 34(4). - P. 314-317.

2. Variations in coronary artery disease secondary prevention prescriptions among outpatient cardiology practices: insights from the NCDR (National Cardiovascular Data Registry) / T. M. Maddox, P. S. Chan, J. A. Spertus [et al.] // J. Am. Coll Cardiol. -2014. Vol. 63(6). - P. 539-546.

3. Свіщенко $€$. П. Виявлення та лікування артеріальної гіпертензії в Україні: реальність та перспективи / Є. П. Свіщенко // Укр. кардіол. журнал. - 2010. - № 1. - С. 13-16.

4. Про затвердження та впровадження медико-технологічних документів зі стандартизації медичної допомоги при артеріальній гіпертензії : наказ МО3 України від 24.05.2012 № 284 [Електронний ресурс]. - Режим доступу: http://moz.gov.ua/ua/ portal/dn 20120524_384.html - Назва з екрану.

5. Уніфрікований клінічний протокол медичної допомоги. Артеріальна гіпертензія. Первинна медична допомога (догоспітальний етап). Вторинна (спеціалізована) медична допомога (2012 рік) // Артериальная гипертензия. - 2012. - № 1. - C. 67-95.

6. Князевич В. М. Розвиток національної системи охорони здоров'я: стан, перспективи та шляхи розбудови / В. М. Князевич // Східноєвропейський журнал громадського здоров'я. - 2008. № 3 (3). - C. 23-37.

7. Гречишкіна Н. В. Вивчення обізнаності та ставлення лікарів первинної ланки щодо профрілактики неіндрекційних захворювань / Н. В. Гречишкіна, Т. С. Грузєва // Сімейна медицина. - 2015. № 6. - C. 22-24.

8. Обґрунтування сучасних освітніх програм з профілактики неінфекційних захворювань / Д. Д. Дячук, Т. С. Грузєва,
Ю. С. Мазепа, Г. В. Іншакова // Східноєвропейський журнал громадського здоров'я. - 2016. - № 1 (26). - С. 79-80.

9. Коваленко А. В. Медико-організаційні недоліки профілактики хвороб системи кровообігу в Україні та шляхи їх подолання / А. В. Коваленко, В. І. Клименко // Вісн. соц. гігієни та орг. охорони здоров'я України. - 2014. - № 4. - С. 12-16.

10. «Нужна ли реабилитация пациентам после коронарного шунтирования?» : интервью с чл.-корр. РАН О. Л. Барбараш // Русский медицинский журнал. - 2016. - № 19. - С. 1254-1256.

11. Навчук І. В. Розробка та обґрунтування моделі первинної та вторинної профрілактики артеріальної гіпертензії у сільського населення : автореф. дис. на здобуття наук. ступеня канд. мед наук : 14.02.03 / Навчук Ігор Васильович; Національний медичний університет імені О. О. Богомольця. - К., 2009. - 33 с.

12. Банк даних сайту Державної служби статистики України: http://database.ukrcensus.gov.ua/MULT/Dialog/statfile_c.asp

13. Про затвердження та впровадження медико-технологічних документів зі стандартизації медичної допомоги в частині профрілактики серцево-судинних захворювань : проект наказу МО3 України [Електронний документ]. - Режим доступу: http:// www.moz.gov.ua/ua/portal/dn_20151222_2.html. - Назва з екрана.

14. Порівняльний аналіз підходів до профрілактики в Європі та Україні / В. М. Лехан, Л. В. Крячкова, О. П. Максименко [та ін.] // Україна. Здоров'я нації. - 2017. - № 3 (44). - С. 159-165.

15. Теренда Н. О. Основні тенденції та прогнозні оцінки загальної та первинної захворюваності на ішемічну хворобу серця в Україні / Н. О. Теренда // Вісник соціальної гігієни та організації охорони здоров'я України. - 2016. - № 3(69). C. 31-35. DOI 10.11603/1681-2786.2016.3.7007

16. Do the five A's work when physicians counsel about weight loss? / S. C. Alexander, M. E. Cox, C. L. Boling Turer [et al.] // Fam. Med. - 2011. - Vol. 43. - P. 179-184. 


\section{OPTIMIZATION OF THE CHANGE OF BEHAVIORS OF PATIENTS AS ONE OF THE ELEMENTS OF THE MODEL OF PREVENTION AND INTENSIVE MEDICAL CARE IN PATIENTS WITH MYOCARDIAL INFARCTION}

Summary. One of the determinants of human health is the way of life. Unfortunately, many patients do not follow the recommendations of doctors on the elimination of risk factors (FR) for the development of cardiovascular pathology. An analysis of the National Health and Nutrition Examination Survey (III, USA) showed a low level of compliance with the recommendations of the American Heart Association for the Prevention of Cardiovascular Disease (CVD).

The aim of the study - adaptation of the " $5 \mathrm{~A}$ " model in patients with FR of myocardial infarction (MI).

Materials and Methods. The study used data from medical records of 288 in-patients with MI. Methods used: data copying, statistical, analytical.

Results and Discussion. The study focuses on such a risk factor for developing myocardial infarction as hypertension. A model of prevention and intensive medical care for patients with myocardial infarction is proposed. As one of the elements of this model, we offer the " $5 \mathrm{~A}$ " model to prevent the development of myocardial infarction in patients with hypertension.

Conclusions. The " $5 \mathrm{~A}$ model" proposed to advise on changing the behavior of patients with $\mathrm{H}$ as a RF for MI will increase the patient's responsibility for their health and ensure their early hospitalization in health care facilities.

Key words: risk factors; myocardial infarction; hypertonic disease; prevention; $5 \mathrm{~A}$ model.

СН. А. Теренда

ГВУз “Тернопольский государственный медицинский университет имени И. Я. Горбачевского” ОПТИМИЗАЦИЯ ИЗМЕНЕНИЯ ПОВЕДЕНИЯ ПАЦИЕНТОВ КАК ОДИН ИЗ ЭЛЕМЕНТОВ МОДЕЛИ ПРОФИЛАКТИКИ И
ПРЕДОСТАВЛЕНИЯ ИНТЕНСИВНОЙ МЕДИЦИНСКОЙ ПОМОЩИ БОЛЬНЫМ ИНФАРКТОМ МИОКАРДА

Резюме. Одним из определяющих фракторов здоровья человека является образ жизни. К сожалению, многие пациенты не соблюдает рекомендации врачей по устранению факторов риска (ФР) развития сердечно-сосудистой патологии. Анализ данных Национального исследования состояния здоровья и питания населения (The National Health and Nutrition Examination Survey, III, США) продемонстрировал низкий уровень соблюдения рекомендаций Американской ассоциации сердца по профрилактике сердечно-сосудистых заболеваний (ССЗ).

Цель исследования - адаптация "модели 5А" у пациентов с фракторами риска развития инсраркта миокарда.

Материалы и методы. В исследовании использованы данные из медицинских карт стационарного больного 288 пациентов с инсрарктом миокарда. Использованы методы: выкопировки данных, статистический, аналитический.

Результаты исследований и их обсуждение. В исследовании акцентируется внимание на таком фракторе риска развития инфраркта миокарда, как гипертоническая болезнь. Предложена модель профилактики и оказания интенсивной медицинской помощи больным инсрарктом миокарда. Одним из элементов этой модели предложено адаптированную "модель 5А" для предотвращения развития инфраркта миокарда у пациентов с имеющейся гипертонической болезнью.

Выводы. "Модель 5А", которую мы предложили для консультирования по изменению поведения пациентов с имеющейся гипертонической болезнью как фрактором риска развития инфаркта миокарда, позволит повысить ответственность пациентов за свое здоровье и обеспечить их раннюю госпитализацию в лечебно-просилактические учреждения.

Ключевые слова: фракторы риска; инфаркт миокарда; гипертоническая болезнь; профилактика; "модель 5А". 